\title{
ISLAMIC EDUCATION: A PRINCIPLE TO DEVELOP RELIGIOUS SOCIETY TO ANTICIPATE NEGATIVE IMPACT OF SOCIAL MEDIA
}

\author{
Solihin Nasrudin \\ Sekolah Tinggi Agama Islam Miftahul 'Ula (STAIM) Nganjuk \\ Nglawak, Kertosono, Kabupaten Nganjuk, Jawa Timur \\ Email: solihin_nasrudin@yahoo.com
}

\begin{abstract}
Abstrack. This study aims to analyze how the Islamic education is able to be the principle of inter-religious harmony to anticipate negative impact of social media use. Islam as a universal religion has proven its ability to encourage the development of science and technology. Social media has emerged along with the development of information technology. The social media is able to facilitate community to communicate and to exchange information, but at the same time social media may also threat the harmony of interfaith relationship. This is due to the misuse of social media by irresponsible individuals who intentionally used social media to create conflict between religious groups. Islamic education is expected to be a foundation to create society with good morale and ethics. This will also produce society with good manner in using social media to avoid negative impact and to create harmony among society and religions Indonesia.
\end{abstract}

Abstrak. Kajian ini bertujuan untuk menganalisis bagaimana
pendidikan Islam mampu menjadi asas kerukunan umat
beragama sebagai antisipasi dampak negatif dari perkembangan
medsos (media sosial). Islam sebagai agama yang universal telah
terbukti sejak kelahirannya telah mendorong perkembangan
ilmu pengetahuan dan teknologi. Seiring dengan perkembangan
teknologi komunikasi berkembang pula medsos yang
memudahkan masyarakat dalam berkomunikasi saling dan saling
bertukar informasi, namun dibalik itu semua tersimpan ancaman
terhadap kerukunan antar umat beragama. Hal ini mengingat
terdapat oknum yang sengaja memanfaatkan medsos untuk
menciptakan konflik horizontal antar umat beragama.
Pendidikan Islam yang dirancang berdasarkan nilai-nilai agama 
Vol. 14, No. 1, Juni 2017: 59-76

Islam, hadir untuk menciptakan masyarakat yang memiliki etika atau moralitas, dan dengan beretika dalam memanfaatkan medsos, dampak negatif akan dapat diminimalisir sehingga kerukunan antar umat beragama di bumi Indonesia akan tetap terjaga.

Key words: Islamic Education, Social Media, interfaith harmony

DOI: http:// dx.doi.org/ 10.24239/ jsi.v14i1.466.59-76

\section{Introduction}

Indonesia is known as a plural country with different culture, tribe, customs, language and religion. This is reflected in the slogan "Bhinneka Tunggal Ika" (Unity in Diversity) which is contained in the symbol of Garuda Indonesia and also mentioned in Pancasila. This is a characteristic of Indonesia as a nation state with community pluralism. Among those diversities include religion and culture which has emerged during the long history of the Indonesian state. For long time, Indonesian people have familiar with various religions and cultures that grow and live in the midst of society ${ }^{1}$.

History proves that Indonesia was founded from the spirit of the scholars to uphold the religion values. It is no doubt the philosophy of this nation that is Pancasila based on the values of religions, not only based on humanism or rationalism. This is reflected in the star symbol on the chest of the Garuda Indonesia. This symbol represents the One God, which is a belief of a religion. In Indonesia there are six religions officially recognized by the government. The six religions include: Islam, Catholicism, Protestantism, Hinduism, Buddhism and Konghuchu. Basically, the people of Indonesia with diverse religious backgrounds are able to coexist and tolerate. As a result, the wisdom-based culture can be developed and become an effective communication media

\footnotetext{
${ }^{1}$ Nasrudin Solihin, "Analisis Etika Kurukunan Umat Beragama (Studi Kasus Kabupaten Nganjuk)," Jurnal Lentera: Kajian Keagamaan, Keilmuan dan Teknologi 14, no. 2 (2016): 290-99.
} 
in building the harmony of religious life in particular and the culture of society in general.

Many scholars argue that the basic element of civilization is religion because religion is the most important factor in determining the characteristics of a civilization. For example, Bernard Lewis asserts that Western civilization live with Christian Civilization because the main elements of their civilization is Christianity. Samuel P. Huntington also wrote, "Religion is a decisive central characteristic of civilization". Among the four great civilizations that still exist - Islam, the West, India and China which those all related to Islam, Christianity, Hinduism and Confucianism². Therefore, Indonesians' philosophy of culture is influenced by Islamic religious values which can be used to build its civilization. When the nation integrate religious values to its social life, the nation will not be affected by external negative culture which is not in accordance with local wisdom.

Plurality is a natural phenomenon in Indonesia. We live in plurality and are part of the process of plurality, both active and passive. The plurality infiltrated and involved in every space of society life. Indonesia society must adapt to this plurality of religion. Anti-pluralism attitude is not tolerated, we must be able to practice tolerant behavior to be familiar with plurality. The tolerant behaviors only can be created when Islamic values is properly practiced. The diversity or pluralism of this nation is a unique national treasure which cannot be found in other countries. We have to preserve this condition to avoid the onslaught of globalization culture which tends to erode the local culture. Western culture tends to eliminate the sense of brotherhood within our society. In doing so, we have to work hard and we also need to prepare our generation.

${ }^{2}$ Adian Husaini, Islam Liberal, Pluralisme Agama \& Diabolisme Intelektual (Surabaya: Risalah Gusti, 2005). 21 
The development of science and technology brought positive and negative impacts on our social life. Both impacts can not be avoided because the government policy to develop science and technology neither be avoided. The science and technology is important to improve the level of social welfare. Fir example, the development of information technology has resulted in speed access to information and causes no boundary between the sender and receiver of information. This will certainly bring the ease of communication between society across the globe, but at the same time the technology also bring negative impact to our society.

Current development of information and communication technology is rapid. This causes the emergence of variety social media applications. The social media application can be used easily and cheaply by the community to support their social interaction, communication and information search and real time interaction. If we use conventional media to communicate with other people in different locations, it is certainly expensive and takes a long time. However, with the social media application, humans only need a finger to write a message / information using a smart phone and at the same time the message will be received at a much cheaper cost .

This includes information related to religious diversity in Indonesia. The information will be accessed rapidly and accessible to anyone. Information which is accessed without going through the filter and with invalid source can result in disputes among religious people. Therefore, this study focus on how Islamic education is able to become a foundation in creating harmony among religious believers to avoid negative impact of social media.

\section{Islam and Technology Development}

Since the beginning of Islam, it has paid great attention to the importance of science and technology. The first verse of 
Alquran (eg: verse 1-5) in Q.S. al-'Alaq (96), command human being to read and write in the widest sense. The repetition of word "read" twice in verses 1 and 3 means reading and writing a series of letters into words, or sequences of words, or sequences of words into sentences. It also means researching, observing, studying, classifying, comparing, summarizing, and verifying. All activities contained in this sense of reading is an activity in order to produce science and technology 3 .

Historically Muslims have played important roles preserving knowledge from extinction as a result of political and ideological disputes during centuries. Muslim also contribute greatly to the field of science. Islam encourages the development of science and use it for the benefit of community welfare in accordance with the guidance of Islamic teachings, ${ }^{4}$ which is often referred to as maqasid asy shariah. Islamic awareness of the development of science and technology is also reflected in the policy of the government annual budget (APBN) in the reign of the Messenger of Allah and the four Caliphs era, in which state expenditure was used to ${ }^{5}$ : (1) The spread of Islam, (2) Education And Culture, (3) Development of Science, (4) Infrastructure Development, (5) Development of fleet war and security guards, and (6) Provision of social welfare. From the structure of government spending above, it shows that the development of science and technology was highly prioritized by Islam government.

The budget policy has resulted in the emergence of Muslim scientists in various fields of science, including astronomy, medicine, economics, art, culture and even the development of

\footnotetext{
${ }^{3}$ Abuddin Nata, I/mu Pendidikan Islam (Jakarta: PT. Raja Grafindo Persada, 2009). 253-254.

${ }^{4}$ Mas'ud, Abdurrahman, et. al., Paradigma Pendidikan Islam (Yokyakarta: Fak.Tarbiyah IAIN Walisongo Semarang \& Pustaka Pelajar, 2001). 349.

${ }^{5}$ Adiwarman A. Karim, Ekonomi Makro Islami, 2nd ed. (Jakarta: PT. Radja Grafindo Persada, 2010). 275
} 
Islam itself. Many of Muslim scientists works have been translated into the western countries language in particular English, and the works became the foundation of the development of science and technology in western. In other words, current development of science and technology is the hard work of early Muslim scientists. Therefore, science and technology should continue to be developed and adapted to the needs of humans in general.

\section{Impact of Science and Technology to Social Life}

Socio technology is a study which specifically focus on how technology evolution influence social life. This discipline was born along with the development of technology that impacts the morality and social life. In other words, socio technology focus on relationship between social science with technology. Technological developments can not be separated from the development of social life of society in which the more modern people's lives the more modern technology. It can be argued that the development of technology is positively related to the development and needs of society for the sustainability of life. At this time, almost every aspect life use technology, ranging from communication, transportation to consumption of goods and services.

The development causes the influence of technology to social life, ranging from economic, political, and even religious harmony. World globalization has immediate effect in spreading developments across the globe. A country will be immediately influenced another country from other parts of the world. All of this is the product of the revolution that takes place in the field of communication and the development communication infrastructures ${ }^{6}$.

${ }^{6}$ Mohammad Zamroni, "Perkembangan Teknologi Komunikasi dan Dampaknya Terhadap Kehidupan," Jurnal Dakwah X, no. 2 (2009): 195-211. 208. 
The communications and information revolution across the globe brought both positive and negative implications. It should be noted carefully the positive implications and how to utilize them to enhance social life. In contrary, we should anticipate the negative impact of revolution in communication and information that might influence social, economic, and political ife. In the field of politics, social media has a major impact on political progress, reform and a better climate of democracy in many countries, both in developed and developing countries. A number of political revolutions followed by a change of power in a country was supported by massive raising awareness of society through social media.

Free and uncensored features of social media content have resulted in the exploitation of the technology by political activists to influence and construct a real socio-political movement. The tremendous power of social media produce the hope of enlightenment, however social media also become a threat to social life if it is used to share, influence and mobilize forces for negative and destructive purposes as well as terror and dehumanization ${ }^{7}$. Some social media application has been used for political purposes include Face book, whatsApp, twitter, etc.

In the economic field, the influence of social media is able to accelerate economic activities which in turn accelerate economic growth. Many applications of social media has supported the promotion of e-commerce such as OLX, Kaskus, LAZADA, bukalapak.com, etc. Many companies use social media application to offer goods and services. This allows sellers and buyers not to meet physically in which the sale and purchase transactions are practiced online. The implication is that social media has created more positive trading activities. Most companies and businesses

${ }^{7}$ Tim Pusat Humas Kementerian Perdagangan RI, Panduan Optimalisasi Media Sosial untuk Kementerian Perdagangan RI. (Jakarta: Kementerian Peragangan RI, 2014). 32-33 
build their own social media application to facilitate social interaction and invite customers to participate in online commerce by contributing feedback, commenting, responding, polling and surveying, and sharing information about a product. However, on the other hands negative implications are also created where the increasingly widespread fraud under the guise of online buying and selling.

In the social field, the development of technological communication has encouraged the rebirth of cultural nationalism. The negative side is that the information presented is not all in accordance with national cultural values and norms. This can complicate social relations among societies. Another destructive impact is the faster flow of information which may not all feasible for public consumption. It is like the needle theory, the flow of information spread through social media can easily lead to trust and understanding for users or recipients of information. This means the social media may be used as a tool to disseminate flaws information related to religious issues. This may provoke anger from certain community religion and can also lead to conflict among community religions. Religious conflicts have been frequent in some parts of Indonesia which impact is very detrimental to social life, both materially and immaterial.

\section{Social Media Development and Implication}

Social media is new a technology development last few decades. The emergence of social media due to the human need for communication. The nature of humanity is a social being that requires interaction or communication. Human beings is able to use technology because they have intelligence. They want to get out of trouble, live better, safer, and the also wants to connect with others.

Social media is an online medium which its users can easily participate, share, and create content including blogs, social networks, wikis, forums and virtual worlds. Blogs, social networks 
and wikis are the most common form of social media used by people around the world. Andra Kaplan and Michael Haenlein define social media as "an internet-based application group that builds on the foundation of Web 2.0 ideology and technology, and which enables creation and user-generated content exchange " .8

A social networking service usually consists of representation of each user in the form of profiles, activities, social relationships, and a number of additional services. The service is usually web-based and the users interact via various Internet applications, such as instant messaging, electronic mail and photos or videos sharing. Social networking sites make users easy to share ideas, suggestions, views, activities, information, events, solicitation and interest within an online networks. In addition, other than social networking services, there is also online community service which is more centered on group or collectivity ${ }^{9}$. From the description above it implies that the development of social media application is supported by Internet. Some popular social media developments from 1998 to 2007 are describe in figure 1.

There are al so other social media which are not discussed in this article. Some of social media are still in operation, but some are no longer active because they have been replaced with other social media sites. For example, the users of Skype have declined sharply because the arrival of Whatsapp (WA) in which its features is more complete and interactive than Skype. WhattApp enable users to send messages, video calls, photos and videos more easily.

Social media will always evolve and human beings become more attached to it. We thank to the benefits and functions of

\footnotetext{
${ }^{8}$ wikipedia, "Media Sosial," Wikipedia.org, 2017, https:/ / id.m.wikipedia. org/ wiki/Media_sosial. Accesed 01-04-2017.

${ }^{9}$ Tim Pusat Humas Kementerian Perdagangan RI, Panduan Optimalisasi Media Sosial Untuk Kementerian Perdagagan RI. 13
} 
social media that makes human life easier, more effective and more efficient. The data shows that users of social media is increasing from year to year. In 1995m number of Internet sites were 1 million, then increased to 1.97 billion sites in 2010. In 2014, the Internet users have reached exceeded 2.2 billion or about 30 percent of world population. Meanwhile, Facebook users have reached 1.2 billion in 2014. While YouTube users have reached more than 850 million in $2013^{10}$.

Ficture 1:Milestone of Social Media (1998-2007)
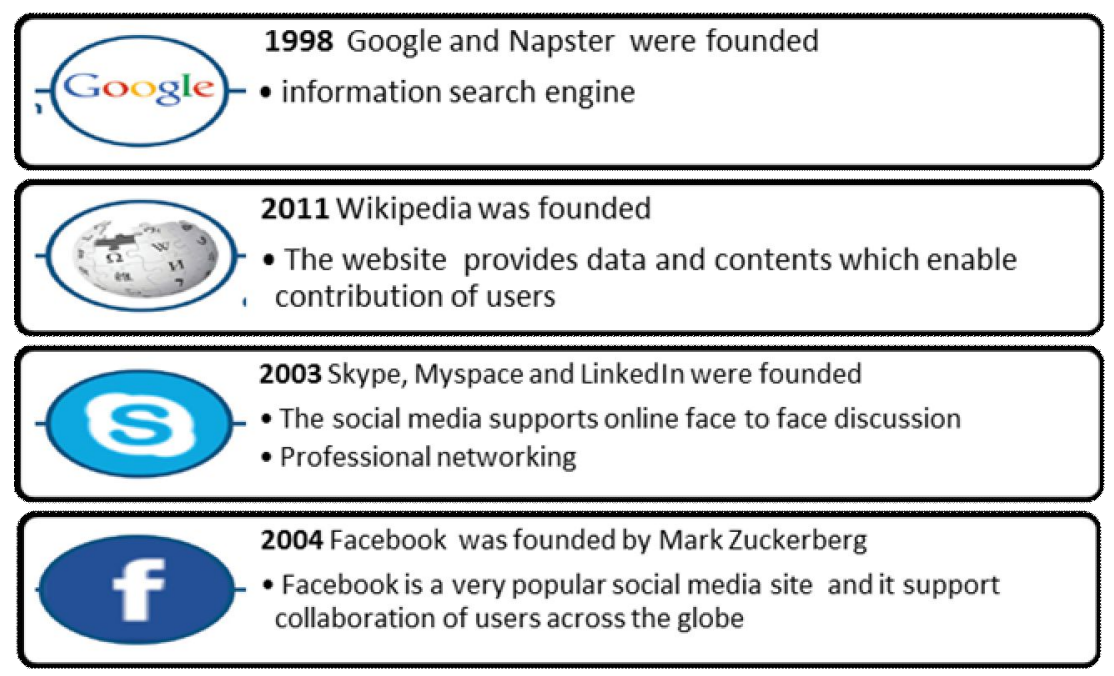

2005 You Tube was founded

You

Tube

- You Tube support online video sharing

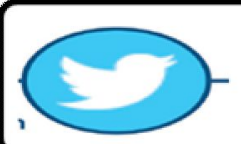

2006 Twitter diluncurkan

- Microblog yang memungkinkan

2007 Hulu dan Wiser

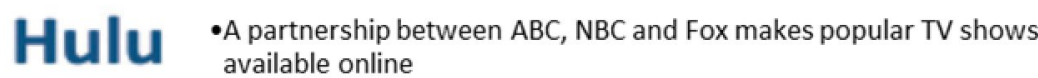

Sources: adapted by the author

${ }^{10}$ bid. 28 
The number of social media users is continually increased over the time due to increase of human needs in communication and information exchange. Social media has have some advantages compared with conventional communication media, among the advantages include:

- Fast, concise, solid and simple in operation;

- Creating a more intense relationship;

- Broad and global reach;

- The cost is cheaper.

With those advantages, the social media will penetrate all aspects of humans life intensively be and it will always be a part of human life. This shows humans will depend very much on technology, including social media in interacting and communicating in online space. The ways to communicate is changing and diverse, such as conventional mail, telephone lines, video call, exchange information, images, videos and online documents exchange.

Therefore, it requires humans wisdom in the use of social media. We need to considered impact of using social media such as content violates the propriety, ethics, values in society, culture and legal norms. If we do not use social media wisely, we may bring negative impact to our life and to communication relationship. The dissemination of information through social media should also wisely be considered because it is consumed by the public. When negative information disseminate into society life, it will can negatively affect the social interaction of the community, especially sensitive information about religion or certain beliefs. Misunderstanding on the content of information might provoke disharmony among interfaith relations.

Moreover there are certain elements who deliberately weaken the power of our nation through the control of social media in order to get certain ben efits. Social media that should be 
used for the purpose of goodness rather than for evil interests ${ }^{11}$. Some people intentionally control the nation political situation through social media. This might weaken the unity and nation because when social media is misused such as spreading the negative issue of a religion. This can ignite the emotions of other religions which raise conflict between religions. Such situation must be realized and controlled before it affect our country unity. We agree that, social media is useful because it eases interaction and communication, the social media might also become a threat it is not wisely used.

\section{Islamic Education and Ethics in Social Media Use}

Moral education is the wisdom of the diversity of values and culture of social life in supporting the country development. The wisdom arises when people opens their mind to live together. People should look at the pluralism in our society. Education must be put in high priority to reduce racial, ethnicity and religion conflict ${ }^{12}$. The social order built on interaction and communication in the digital era will be useless if social media users do not it wisely in particular when the social media is used to disseminate information related to religions.

Therefore, it is appropriate to apply Islamic education in our society. Prof.' Quraish Shihab argues that the purpose of Islamic education is to foster individually and groups to be able to perform their functions as servants of Allah and His caliphs in order to build this world according to His established concepts ${ }^{13}$.

\footnotetext{
${ }^{11}$ Sri Suryono, "Memahami Ancaman Menyadari Jadi Diri Modal Mewujudkan Indonesia Manjadi Bangsa Pemenang," Studium General STAI Miftahul Ula Nganjuk, 09 May 2017(Nganjuk: STAl Miftahul Ula, 2017).

${ }^{12}$ Hamam Burhanuddin, "Pendidikan Islam Dan Karakter Bangsa (Membangun Karakter Bangsa Yang Otentik Melalui Pendidikan Islam)," Jurnal Lentera: Kajian Keagamaan, Keilmuan dan Teknologi 11, no. 2 (2013). 35.

${ }^{13}$ Quraish Shihab, "Peningkatan Peranan Dan Kualitas Pendidik Muslim Dalam Pembentukan Karakter Bangsa" (Surakarta, 2006). Paper Presented at National Seminar "Pembentukan Karakter Bangsa Melalui Pendidikan Islam", UNS Surakarta. 03 April 2006
} 
To be able to implement it all, then the Islamic education not only focus on learning to think paradigm, to do and to be, but also to live together ${ }^{14}$. The paradigm makes the Islamic education not only to create a generation with high intellect but also individuals with high social sensitivity. In this case, Islamic education paradigm should focus on: (1) the development of tolerance, empathy, and sympathy that make the main condition of successful coexistence in religious diversity; (2) clarification of common life values according to the perspectives of religions; (3) emotional maturity; (4) equality in participation; (5) new social contracts and interfaith lifestyles.

This is in line with the view of Islamic teachings which is universal. The task of Islamic education stakeholders is to transform the values of Islamic teachings into contextual with various problems faced by society. This include addressing the challenge of adverse impacts of science and technology to our society. The social order constructed by digital communication era through social media will be destructive if social media is not used wisely. People should practice ethical communication in social media sphere.

Islamic education is an open system. It always growth and develop according the development of science and technology with Muslim society always uphold the principles of sharia. Islamic education not only makes people aware of religion, but also teach people to practice Islam in good manner ${ }^{15}$. When human beings are able to practice their religion wisely, they will posses good characters, ethics and morals. It is the role of Islamic education to address and exploit social media wisely. If an

${ }^{14}$ Harto Kasinyo, "Model Pengembangan Pendidikan Agama Islam Berbasis Multikultural," At-Tahrir: Jurnal Pemikiran Islam 14, no. 2 (2014): 40726. 411.

${ }^{15}$ Ahamad Tafsir, Filsafat Pendidikan Islami: Integrasi Jasmani, Rohani dan Kalbu Memanusiakan Manusia (Bandung: PT. Remaja Rosdakarya, 2006). 226. 
individual has good ethics, then they will able to decide what is good and bad in social media use.

If someone has ethics, then technically impact their behaviour to use social media wisely which includes:

First, a person will keep personal or family information confidential. Publish personal information on social media sites may harm other individuals. Personal data or information which considered private includes phone number, home address, and bank account information. Publicity such information on social media sites should be avoided. Second, practice ethical communication and do not use harsh words because good communication, such as the use of polite language, can prevent conflict on social media sites. Certain terms which are considered not polite, blasphemous and disrespectful should be prevented.

Thirdly, individuals should not disseminate content that may disrupt harmony of inter-ethnic, religious, and racial relations, whether in the form of texts, photographs, pictures, videos or illustrations. These may cause negative impact on harmony between the users of social media with ethnic background diversity. Mutual respect is a principle that should be maintained in using social media. Fourth, filtering negative content and information as well as tracking the original source of information before disseminating it to avoid news that may offend society.

Fifth, with regard to the intellectual property rights of others, ethical social media users will appreciate the work of others by stating the original source in particular when it is used for a scientific purposes, artistic and cultural work. Sixth, social media users should have comprehensive knowledge when they comment on news, topics and other issues. Seventh, social media users should give their opinion according to real facts and valid data. Although in social media there is freedom for users to 
express opinions, but opinions that may cause conflicts or radical should not be published

Eighth, social media users do not accuse, attack, or defame others. If this is done and any party is harmed, then it may end up in the realm of law, where the users may be reported to the authorities for defamation, for violating Article 27 and Article 28 of electronic Transaction Law. Ninth, social media users should not use social media during unstable emotion because such conditions will affect the content of the published opinions. When emotion is unstable, an individual may publish information which not in accordance with public interest and ethics.

Tenth, users should use social media for positive purposes only and deliver social media contents in good manner. Positive use of social media produce positive social relation and avoid to hurt others. Eleventh, users should addressing any news in social media wisely. This is because many users of social media are deliberately creating lack harmonization in a society, such as pitting interfaith communities by spreading the negative issue of a religion. Wisdom and virtue in the use of social media can avoid the destruction of religious harmony. Social media should really be used as a means to share goodness, optimism, happiness, mutual help, and mutual respect.

Our community social life, in particular plural society in Indonesia, is very vulnerable to conflict. Some conflicts have occurred before such as rebellion conflict, racial conflict and inter religion conflict. The absence self censorship in social media use is the beginning of the disaster in our society relationship. Our society should be equipped with ethics or morality from Islamic education system. In this case Islamic education play important role in education our Muslim society to use social media wisely. As a result, Islamic education may become the foundation to 
maintain religious harmony and to filter negative impact of social media use.

\section{Conclusion}

From the above discussion, some conclusions is made as follows:

From beginning Islam whether in normatively, philosophically, and pragmatic applicative, Islam has paid great attention to the importance of science and technology for the survival of human life and the establishment of a faithful religion.

The development of technology can not be separated from the development of social life. Technological developments are also positively related to the development and needs of society for the sustainability of life. Humans use technology in all aspects of life, such as for communication, transportation, commerce and services. As a result, technology have influence our social, economic, political, and the harmony of religious life.

The development of information technology has cause the emergence of social media and it become an important tool for communication. Information disseminated through social media may bring positive and negative impact to our society depending on what information is disseminated. Positive information may enhance our social life, but negative information may disrupt our social life harmony.

Islamic education aims to create ethical society. Society with good manner will use social media wisely and disseminate positive contents to strenghthens our society life as well as fostering our country unity. Better Islamic education for our society will also produce self cencorship ability within our society during the use of social media sites. They also will able to filter negative content of social media sites. 


\section{References}

Burhanuddin, Hamam. "Pendidikan Islam dan Karakter Bangsa (Membangun Karakter Bangsa yang Otentik Melalui Pendidikan Islam)." Jurnal Lentera: Kajian Keagamaan, Keilmuan Dan Teknologi 11, no. 2 (2013).

Husaini, Adian. Islam Liberal, Pluralisme Agama \& Diabolisme Intelektual. Surabaya: Risalah Gusti, 2005.

Karim, Adiwarman A. Ekonomi Makro Islami. 2nd ed. Jakarta: PT. Radja Grafindo Persada, 2010.

Kasinyo, Harto. “Model Pengembangan Pendidikan Agama Islam Berbasis Multikultural." At-Tahrir: Jurnal Pemikiran Islam 14, no. 2 (2014): 407-26.

Mas'ud, Abdurrahman, et. al., Paradigma Pendidikan Islam. Yokyakarta: Fak.Tarbiyah IAIN Walisongo Semarang \& Pustaka Pelajar, 2001.

Nata, Abuddin. IImu Pendidikan Islam. Jakarta: PT. Raja Grafindo Persada, 2009.

Shihab, Quraish. "Peningkatan Peranan dan Kualitas Pendidik Muslim dalam Pembentukan Karakter Bangsa." Surakarta, 2006. Paper Presented at National Seminar "Pembentukan Karakter Bangsa Melalui Pendidikan Islam", UNS Surakarta. 03 April 2006.

Solihin, Nasrudin. "Analisis Etika Kurukunan Umat Beragama (Studi Kasus Kabupaten Nganjuk)." Jurnal Lentera: Kajian Keagamaan, Keilmuan dan Teknologi 14, no. 2 (2016): 290-99.

Sri Suryono. "Memahami Ancaman Menyadari Jadi Diri Modal Mewujudkan Indonesia Manjadi Bangsa Pemenang." Studium General STAl Miftahul Ula Nganjuk, 09 May 2017. Nganjuk: STAI Miftahul Ula, 2017.

Tafsir, Ahamad. Filsafat Pendidikan Islami: Integrasi Jasmani, 
Vol. 14, No. 1, Juni 2017: 59-76

Rohani dan Kalbu Memanusiakan Manusia. Bandung: PT. Remaja Rosdakarya, 2006.

Tim Pusat Humas Kementerian Perdagangan RI. Panduan Optimalisasi Media Sosial Untuk Kementerian Perdagangan RI. Jakarta: Kementerian Peragangan RI, 2014.

wikipedia. "Media Sosial." Wikipedia.org, 2017. https:/ / id.m.wikipedia.org/ wiki/ Media_sosial.

Zamroni, Mohammad. "Perkembangan Teknologi Komunikasi dan Dampaknya Terhadap Kehidupan." Jurnal Dakwah X, no. 2 (2009): 195-211. 